\title{
CULTURAL DIMENSION OF REVOLUTION: NEW IMAGES OF MAN
}

\author{
Maksim M. Zagorulko \\ Center for Study of the Battle of Stalingrad, Volgograd, Russian Federation
}

Irina A. Petrova

Volgograd State Medical University, Volgograd, Russian Federation

Irina K. Cheremushnikova

Volgograd State Medical University, Volgograd, Russian Federation

\begin{abstract}
The turning points of the history are characterized by people's active participation in one of the most natural for the man social activity - the creation of new self-images. Being incorporated in these images, people are able to realize their involvement in social events. The new ideas and meanings acquire "corporality" in the new images of man and get accumulated in them becoming the reality accessible for the majority of people. Being revealed in the images of people, new ideas obtain real bodies, penetrate to the living tissue of culture, transform into reality, which can be perceived. Man uses their body as a tool for coding significant cultural meanings. The rules of behavior, public manners, the elements of appearance and clothing become the material signs of nonmaterial ideas. They transform into the complex distinguishing system, which allows for the consolidation of people with similar viewpoints. The creation of new visual images comes in hand with the experiments in the field of creating a new language.

The authors demonstrate the appearance and creation of such images using the examples of Great French revolution, the revolutionary transformations of Post-reform Russia, Great Russian revolution, cultural revolution of the Chinese People's Republic.

M.M. Zagorulko and I.A. Petrova represent common theoretical approaches to the analysis of cultural - revolutions of the New Time and Modern period, to understanding the principles of interaction between the "old" $\vec{\sim}$ and the "new" in culture. I.A. Petrova carries out analysis of theoretical disputes of A.V. Lunacharsky and A.A. Bogdanov about the possibility of constructing "pure proletarian culture".

I.K. Cheremushnikova proves the significance of emblematic images in the culture, the connection between body self-representation and the privileged meanings, adopted during the revolution; she represents numerous examples of man becoming the carrier of new cultural meanings in the process of self-representation.

Key words: cultural revolution, cultural practices, image, cultural-historical invariant of image, traditional culture, mass consciousness, collective mental ideas.

Citation. Zagorulko M.M., Petrova I.A., Cheremushnikova I.K. Cultural Dimension of Revolution: New Images of Man. Vestnik Volgogradskogo gosudarstvennogo universiteta. Seriya 4, Istoriya. Regionovedenie. Mezhdunarodnye otnosheniya [Science Journal of Volgograd State University. History. Area Studies. International Relations], 2017, vol. 22, no. 6, pp. 22-29. (in Russian). DOI: https://doi.org/10.15688/jvolsu4.2017.6.2

\section{РЕВОЛЮЦИЯ В КУЛЬТУРНОМ ИЗМЕРЕНИИ: НОВЫЕ ОБРАЗЫ ЧЕЛОВЕКА}

\author{
Максим Матвеевич Загорулько
}

Центр по изучению Сталинградской битвы, г. Волгоград, Российская Федерация 


\section{Ирина Александровна Петрова}

Волгоградский государственный медицинский университет, г. Волгоград, Российская Федерация

\section{Ирина Кабдрахимовна Черемушникова}

Волгоградский государственный медицинский университет, г. Волгоград, Российская Федерация

Аннотация. В переломные моменты истории люди активно включаются в одну из самых естественных для человека социальных практик - создание новых образов самого себя, встраиваясь в которые, они способны ощутить свою сопричастность происходящему. Идеи-смыслы обретают свою «телесность» в новых образах человека, аккумулируются в них, становятся данностью, доступной для большинства. Проявляя себя в обликах людей, новые идеи наполняются телесностью, проникают в живую ткань культуры, превращаются в реальность, доступную для чувственного восприятия. Человек использует свое тело как инструмент для кодировки значимых смыслов. Правила общения, манеры, элементы внешности и одежды становятся материальными выразителями нематериальных идей. Они превращаются в сложную опознавательную систему, позволяющую консолидироваться людям похожих взглядов. Параллельно с созданием новых визуальных образов идут эксперименты в области создания нового языка.

Авторы приводят примеры возникновения и создания таких образов на примере Великой французской революции, революционных преобразований пореформенной России, Великой российской революции, культурной революции Китайской Народной Республике.

М.М. Загорулько и И.А. Петрова сформулировали общие теоретические подходы к анализу культурных революций Нового и Новейшего времени, к пониманию принципов взаимодействия «старого» и «нового» в культуре. И.А. Петрова проанализировала теоретические споры А.В. Луначарского и А.А. Богданова о возможности создания «чистой пролетарской культуры».

И.К. Черемушникова обосновала значение символического образа в культуре, показала связь телесного образа с привилегированными смыслами, которые санкционирует революция, привела многочисленные примеры того, как через «образы самого себя» присваивает новые культурные смыслы и становится их носителем.

Ключевые слова: культурная революция, культурные практики, образ, культурно-исторический инвариант имиджа, традиционная культура, массовое сознание, коллективные ментальные представления.

Цитирование. Загорулько М. М., Петрова И. А., Черемушникова И. К. Революция в культурном измерении: новые образы человека // Вестник Волгоградского государственного университета. Серия 4, История. Регионоведение. Международные отношения. - 2017. - Т. 22, № 6. - С. 22-29. - DOI: https://doi.org/10.15688/ jvolsu4.2017.6.2

Влияние революций на переустройство общества выражается не только в радикальных экономических и политических преобразованиях, но и в тех «новых образах самого себя», которые создает человек. В переломные моменты истории люди словно бы включаются в одну из самых интересных, и, в то же самое время, самых естественных для человека социальных практик - создание новых образов, встраиваясь в которые, они способны ощутить свою сопричастность происходящему.

В период революций новая элита становится носителем новых революционных идей, именно в ее среде формируется облик не только нового общества, но и нового человека. Однако чтобы проникнуть в ментальность тех, кого историки называют «простецами», революционные идеи-смыслы сначала должны упроститься до степени, понятной большинству, и лишь затем встроиться в повседневность. Если этого не произойдет, они останутся культурой элитарного меньшинства или совсем исчезнут.

Новые «образы самого себя», с которыми человек имеет дело в реальном опыте повседневной практики, становятся своеобразным мостом между «миром идей», невидимых и неосязаемых, и реальным, осязаемым «миром повседневности». Проявляя себя в обликах людей, новые идеи наполняются телесностью, проникают в живую ткань культуры, превращаются в реальность, доступную для чувственного восприятия. Человек способен использовать свое тело как инструмент для кодировки самой сложной информации. Культурные коды революционных преобразований, передаваемые через вербальную ин- 
формацию, даже если это понятные лозунги и слоганы, всегда имеют смысловой зазор, возможность множественных толкований, и поэтому они трудны для осознания и присвоения. Визуальная информация (образы) прямо погружает человека в эти смыслы, поскольку передает их без «посредников», и оппозиция «видимого» и «невидимого» миров исчезает в восприятии человека - носителя культуры.

М. Фуко писал, что «основополагающие коды культуры управляют ценностями... определяют для каждого человека эмпирические порядки, с которыми он будет иметь дело, и в которых будет ориентироваться» [12, с. 33]. Каждая эпоха создает набор санкционированных обществом образов, в которых выражает привилегированные и значимые смыслы. Иными словами, через новый образ происходит переход идей и социальных установок из сферы сознания в сферу поведения. Такое заданное в определенном контексте восприятие образа регулируется новой моралью и новой идеологией и играет направляющую, а часто и репрессивную роль [14, с. 57].

Буржуазные революции Нового времени были первым опытом, когда широкие народные массы впервые начали активно принимать участие в создании новых образов эпохи. Если раньше нормативный образец в культуре создавался элитой в соответствии с ее идеологическими и эстетическими установками, а все другие социальные группы только потребляли готовый культурный продукт (подражали элитам в меру своих финансовых возможностей), то теперь они сами становится активными создателями новых образов. Традиционное деление на «заказчиков» и «потребителей» нормативных образцов в культуре становится архаичным явлением и в ХХ в. выльется в феномен, который Х. Ортега-и-Гассет назовет «восстанием масс» (цит. по: [13, с. 104]).

Самым заметным политическим событием XVIII в. была Великая французская революция. Порвав со старыми традициями, она пыталась создать новые революционные идеалы, олицетворяющие идеи свободы, равенства и братства всех социальных групп. Революция затронула даже самые архаичные и отсталые слои населения и втянула их в воронку политической и культурной жизни. Замечательным является тот факт, что, Фран- цузская революция попыталась впервые в истории путем реформ сверху создать новый образ гражданина. За воплощение этой идеи взялся талантливейший художник Франции Ж.-Л. Давид. Он создал ряд эскизов типовых костюмов, которые, как ему казалось, воплощали идеи Французской республики. На самом деле они явили собой причудливую смесь псевдоримского величия и псевдонародной простоты. Эти вычурные костюмы не стал носить никто, кроме последователей Давида. Придуманный образ не прижился, да и не мог прижиться, поскольку новый культурный образ рождается как результат неосознанных усилий целого поколения. Возникающий культурно-исторический образ является результатом сложнейшего взаимодействия «коллективной души» с «коллективным телом».

С началом кардинальных социальных изменений, приведшим к стиранию граней между сословными группами и демократизации общества, все сословия, в том числе и низы, начинают принимать участие в создании собственных обновленных или абсолютно новых образов. Старая привычная система знаков, которая была слишком прямолинейной и отражала только наиболее значимые характеристики (пол, возраст, религиозную принадлежность, социальный и экономический статус), усложнилась. В новой системе нашли отражения политические пристрастия, эстетические вкусы, профессия и образование.

Общество было так увлечено происходящим, что откликалось на все более-менее заметные политические события. Так, после казни Шарлоты Корде, убийцы Марата, во французском обществе вошло в моду красное ожерелье или красная лента на шее, как напоминание о ноже гильотины. Роялисты, выступавшие за возврат монархии, надевали одежды, рождающие ассоциации с пышностью королевского двора; люди, поддерживающие идеи равенства, заимствовали костюм у горожан и крестьян и ввели в моду фригийский колпак каторжника, грубые башмакисабо и подтяжки, карманьолку, санкюлоты. Это было одним из первых примеров просачивания моды снизу вверх.

Костюм менялся очень быстро, приобретая экстравагантные формы, открыто нарушал общепринятые нормы. Так появился 
аристократический клуб, куда входили дворяне, у которых кто-либо из родных погиб на гильотине. Они ввели в моду «прическу жертвы» - коротко остриженные затылки, как у осужденных на казнь, чем совершенно шокировали добропорядочных буржуа средней руки. Вслед за «клубом жертв» появились совершенно эпатажные персонажи: инкруаябли и мервейезы («невероятные», «дивные»). В их образах и поведении выразилось творчество «золотой молодежи» Франции, которая протестно относится ко всему традиционному и окостеневшему в культуре.

XIX в. - век индустриализации и урбанизации, век образования и науки, век политических революций и модернизма в искусстве, создаст необычайное разнообразие взаимодействующих в культуре образов, которые уже не позволяют создать более-менее единый образ отдельного сословия или эпохи. Образы новых социальных групп, выходящих на историческую авансцену, создаются не по принципу подражания и копирования высших сословий. Напротив, они стремятся теперь как можно больше визуально отличаться от них, демонстративно провозглашают собственное видение экономических, политических, эстетических идеалов. Даже внутри одной социальной группы или класса создаются разные образы. Крупная буржуазия стремится стать наследницей образа жизни уходящей аристократии и примеряет на себе ее образ жизни. Средние и мелкие буржуа восполняют недостаток богатства повышением уровня образованности, вкуса и стиля. На создание новых образов заметное влияние оказала философия и романтическая литература XIX в., в моду вошли костюмы и манеры литературных героев Мопассана и Диккенса. Разночинцы, интеллигенция, служащие-группы, которые раньше вовсе не имели сколько-нибудь выразительного и узнаваемого образа, теперь целенаправленно создавали его как образ прогрессивного деятельного человека. Он был совершенно не похож на все известные ранее, отличался простотой и, в то же время, демонстрировал сдержанное благородство.

Новые смыслы, еще более чем в предыдущий период, передаются через знак, который становится едва заметным, но все более нагруженным смыслом (в терминологии
Р. Барта - «пустячок» и «не знаю что»). Это уже не тяжеловесные знаки-иконы, понятные всем. Теперь это скорее утонченные знакисимволы, многие из которых создаются намеренно, чтобы «свои» опознавали «своих». Человек быстро учится искусству нагружать свой образ особыми знаками, передающими в небольших деталях огромные объемы информации. Это была своего рода культурная революция, которая превратила сигналетику костюма в особый язык общения. Все элементы и детали одежды были продуманы, поскольку становились материальными выразителями нематериальных идей, глубоких смыслов. Они превращаются в сложную опознавательную систему, позволяющую консолидироваться людям похожих взглядов или членам одного сообщества. В «Саге о Форсайтах» Дж. Голсуорси метко подмечает этот факт, так описывая поведение одного из своих героев: «...после провала всеобщей стачки и забастовки горняков 1921 года, инстинктивно почувствовав, что революция на долгое время отсрочена, Сомс опять стал носить цилиндр».

Пореформенная Россия второй половины XIX в. - это время появления свободно мыслящей революционно настроенной молодежи, которая также стремилась создать и распространить среди других слоев новую систему ценностей. Образованная петербургская молодежь была охвачена идеей прогресса и стремилась «выдавить из себя раба» и «стряхнуть с себя ветхого человека» [4, с. 25-26].

Нравы шестидесятых годов XIX в. считали главной задачей человека-борца «улучшать собственную природу» и «уничтожать природную пошлость» [4, с. 32]. Женщины делали все возможное, чтобы не походить на «разряженных кукол» и «кисейных барышень». Они перестали затягиваться в корсеты, носить пышные платья, совершенно исчезли фальшивые накладки, оборки, кружева. Молодые «прогрессистки» надевали простое черное платье безо всяких украшений. Единственным допустимым украшением были скромные воротнички и манжеты. Именно такие образы запечатлели «передвижники» [4, с. 36]. Если молодая женщина появлялась в обществе «во всем блеске комильфотности», ее обвиняли в «допотопнос- 


\section{ПОЛИТИЧЕСКИЕ НАУКИ И РЕГИОНОВЕДЕНИЕ}

ти взглядов» и «индифферентизму к общественному делу» [4, с. 108].

Молодые мужчины также старались избегать всего, что делало их похожими на «чиновалов» и «чинодралов». Демократизация костюма студенческой молодежи Петербурга, как и во времена Французской революции, проявлялась в намеренном упрощении костюма, в демонстративной эклектике, приверженности костюму национальных окраин (кафтаны, шаровары, косоворотки), в ношении откровенно «революционных» предметов одежды, таких как польская «конфедератка» $[8$, с. 106]. Новая революционная мода требовала аскетизма в прическе, особенно в женской. Прически, которые носили следы профессиональной укладки, язвительно называли «эшафотом» или «куафюрой», а их владелиц высмеивали за верность «туалетным принципам» [4, с. 279].

Революционные веяния коснулись речи и риторики. Революционно настроенная молодежь периода Французской революции ввела некогда моду на слегка картавое произношение звука «р», с которого начиналось слово «революция». Молодежь шестидесятых годов выражалась «цветисто» и «фразисто», в «высокопарном стиле». В риторике этого времени словам, которые ассоциировались со старым образом жизни, противостояли новые, такие как «алтарь общественной пользы», «научные интересы», «труд на благо ближнего», «носители прогрессивных идеалов», «колыбель новорожденного человечества» $[4$, с. $218-220]$.

XX в. - век мировых войн и революционных движений также дает нам не только образцы «культурных революций» и изменений парадигмальных оснований изобразительного искусства и культуры в целом, но и быстро меняющегося облика человека. Войны и революции втягивают в активную политическую практику все более широкие массы, меняя их привычный уклад жизни. Широко известные споры А.В. Луначарского и А.А. Богданова о «пролетарской культуре» открывают дорогу разноликим культурным революциям века. Идея «чистой пролетарской культуры», создаваемой с нуля самим пролетариатом, сформулированная А.А. Богдановым [3, c. 413-414, 457], была встречена правитель- ством с недоверием и иронией (первоочередной задачей была элементарная грамотность, умение читать, писать и понимать прочитанное). Однако она была с энтузиазмом подхвачена представителями Серебряного века. Они открыли дорогу беспощадной критике старой академической культуры, которая воспринималась ими как феномен, пораженный «старчеством, немощью, оскоплением духа» $[2$, c. 67]. Задачу по созданию новой пролетарской культуры взяли на себя революционные деятели искусства через множество своих организаций (ЛЕФ, Пролеткульт, РАПП), большую роль в создании концепции нового искусства сыграл театр и театральные деятели, в частности театр Вс. Мейерхольда. Это была деятельность элит, которые стремились вторгнуться в самую гущу революционных преобразований.

Пролетарская революция 1917 г. сформировала новый «эстетический тип предельной функциональности и предельного аскетизма, при котором все, что напоминало об ушедшей, насильственно отринутой бытовой культуре, воспринималось как враждебное, идеологически чуждое. Красная косынка, рубахакосоворотка армейского образца, кожаная куртка, фуражка, широкий ремень, сапоги или обмотки определяли облик улиц и главенствовали в учреждениях. Европейский костюм и галстук представителей верховной власти были знаком особых привилегий, и их не смели носить другие» [5, с. 48]. На смену девушкам буржуазно-мещанского прошлого пришли курсистки и прогрессистки «с революцией во взоре». Об этом свидетельствуют даже частушки: «Выньте серьги, бросьте кольца, / Вас полюбят комсомольцы»; «Девки старого режима, не ходи на улицу, / Мы, ребята-комсомольцы, задерем, как курицу» [11, с. 60].

В ходе культурной революции рождался «новый», «советский» сверхчеловек. Он создавался как носитель «аполлоновского совершенства» и «дионисийского характера борца» $[6$, c. 34]. Новая советская мода, в соответствии с декларациями, должна была противостоять мещанству и вычурности, была призвана стать идеалом хорошего вкуса, воспитанного на лучших образцах народной и мировой культуры. Однако все это лишь внешняя сторона происходивших процессов. На самом же деле од- 
ной из самых главных задач и черт советской моды стала тотальная нивелировка личности. И это вполне объяснимо, поскольку понятия «коллективизм» и «индивидуализм» в новой советской терминологии противопоставлялись. Основой нового общества был коллектив, а не личность, а коллективизм становился привилегированной и безусловной ценностью. Провозглашение коллективизма как преимущества социализма подчиняло личность не только интересам коллектива, но и новой идеологии: в новом обществе «человек действовал не как гражданин и самоценный индивид, а как невычленяемая часть целого» [1, с. 4].

Революционные изменения коснулись не только элит и пролетариата, но и самой традиционной среды, и происходили в гуще крестьянской жизни. После Февральской революции 1917 г. все более активно распространяются идеи непротивления злу насилием, идеи христианского социализма благодаря активной деятельности толстовцев и протестантов, создаются различные общества, целью которых является преодоление хаоса в современной жизни на основе соблюдения христианских заповедей (староверы, протестанты) [10]. Популярной становится идея усовершенствования человеческого бытия на базе идеи мирного труда без эксплуатации человека человеком. С подачи интеллигенции в сельском хозяйстве начинают внедряться новые формы хозяйствования, использовавшие позитивный пример протестантских и сектантских общин, практиковавших с середины XIX в. коллективный, иногда коммунитарный образ жизни в деревне [7].

Параллельно с созданием новых визуальных образов шли эксперименты в области создания нового языка. Эксперименты над языком начались еще в годы Серебряного века. Символическим началом изобретения новых слов «нового мира» стало знаменитое стихотворение Велимира Хлебникова «Заклятие смехом»: «О, рассмейтесь, смехачи! / O, засмейтесь, смехачи! / Что смеются смехами, что смеянствуют смеяльно...» Эти эксперименты были продолжены пролеткультовцами, а позже - подхвачены властями, которые занялись формированием нового «партийного языка». Для выражения нового мировоззрения создавалась новая фразеология, для но- минации новых явлений вводились новые слова. Острые, хлесткие передовицы партийных газет были полны новых слов-штампов, ярлыков и цитат вождей. Особой популярностью пользовался суффикс «изм», поскольку с его помощью клеймились отрицательные явления (троцкизм, хвостизм, меньшевизм и т. д.). Если в Толковом словаре В.И. Даля было 79 слов на «изм», то в новом словаре (1935-1940 гг.) их было больше четырехсот. Новые ценностные смыслы выражали и новые имена: Вилен, Владлен, Мэлс, Гертруда, Красара. В повседневную жизнь вводились не только новые революционные праздники - к новой реальности весьма успешно приспосабливали старые. Появились «красные пасхи» и «красные свадьбы». Так из причудливой смеси старых привычек и новых революционных идей рождалась новая культура повседневности.

Для того чтобы продемонстрировать универсальность практики создания новых образов можно обратиться к опыту самой радикальной из всех культурных революций ХХ в., которая происходила в Китае в 1966-1976 гг. [9, с. 17-18]. В Китае, также как и везде, при внедрении новых революционных идей активно создавались новые образы. А для того, чтобы они проникали сквозь тысячелетние слои традиционной ментальности, были использованы понятные носителям культуры глубинные конфуцианские мифологемы. Например, широко использовалась нумерологическая символика. Чтобы сделать наглядными идеи революции и народной республики, был использован знаменитый «костюм Мао». Хотя сам он представлял собой стандартный полувоенный френч европейского образца, каждая деталь в нем имела особое символическое значение, понятное китайцам: «пять пуговиц символизировали пять ветвей власти; три пуговицы на манжетах - три народных принципа республики; четыре кармана олицетворяли четыре добродетели, а карман внутри право народа смещать политиков» $[15$, с. 220$]$.

Значение «образа самого себя» как инструмента приобщения индивида к коду современной ему культуры трудно переоценить. Пользуясь терминологией Г.К. Юнга, можно сказать, что типические имиджи - это «инстинкты, выраженные в форме образов». Одежда и предметы, которыми окружает 
себя человек, вначале действуют как функциональные единицы, но очень скоро перестают быть таковыми и превращаются в знаки. Заданный новыми реалиями культуры образ способствует непосредственной объективации значимых норм и ценностей, позволяет им стать частью повседневной жизни человека. В эпоху войн и революций общество вступает в период, когда в хаосе разрушаются культурные коды старой эпохи, а рождение нового общества зависит не столько от его способности к созданию новых культурных смыслов и культурных кодов, сколько от умения сделать эти смыслы осязаемыми через образы самого человека.

\section{СПИСОК ЛИТЕРАТУРЫ}

1. Апресян, Р. Г. Демократия и гражданство / Р. Г. Апресян, А. А. Гуссейнов // Вопросы философии. - 1996. - № 7. - С. 3-16.

2. Бенуа, А. Н. Дневник 1916-1918 годов / А. Н. Бенуа. - М. : Захаров, 2010. - 168 c.

3. Богданов, А. А. Вопросы социализма: Работы разных лет / А. А. Богданов. - М. : Политиздат, 1990. $-479 \mathrm{c}$.

4. Водовозова, Е. Н. На заре жизни. Мемуарные очерки и портреты. В 2 т. Т. 2 / Е. Н. Водовозова. - М. : Худож. лит., 1987. -430 с.

5. Кирсанова, Р. «Гимнастерка», «Джимми» и «полпред»... / Р. Кирсанова // Родина. - 1997. № 11.- C. 46-50.

6. Климова, С. М. Миф и симулякр / С. М. Климова, О. В. Губарева // Человек. - 2006.- № 6. C. $34-37$.

7. К родным берегам: о реэмиграции казаков«некрасовцев» из Турции в СССР в 1920-е гг. / публ. подгот. О. Ю. Редькина // Исторический архив. 2003. - № 5. - C. 109-126.

8. Куприянов, А. Дурацкие костюмы / А. Куприянов // Родина. - 2009. - № 1. - С. 104-107.

9. Петрова, И. А. Культурные революции ХХ в.: разрыв с традиционной культурой или ее продолжение? / И. А. Петрова, Е. А. Авходеева // Вестник Волгоградского государственного университета. Серия 7 , Философия. Социология и социальные технологии. - 2014. - № 1 (21). - С. 13-20.

10. Редькина, О.Ю.Христианские политические партии на Нижней Волге в 1917 году / О. Ю. Редькина // Вестник Волгоградского государственного университета. Серия 4, История. Регионоведение. Международные отношения. - 2012. - № 1 (16). C. 121-126. - DOI: http://dx.doi.org/10.15688/ jvolsu4.2012.1.6.
11. Смирнова, Т. Советская повседневность, народное творчество и массовая культура 20-30 гг. / Т. Смирнова // Историк и художник. - 2003. - № 2. C. 56-74.

12. Фуко, М. Слова и вещи / М. Фуко. - СПб. : Академия, 1994. -408 c.

13. Черемушникова, И. К. Имидж в эпоху «восстания масс» / И. К. Черемушникова // Известия Волгоградского государственного технического университета. Серия «Проблемы социально-гуманитарного знания». -2010 . - № 9 (69). - С. 103-107.

14. Черемушникова, И. К. Имидж как смысловая реальность культуры / И. К. Черемушникова. Волгоград : Изд-во ВолгМУ, 2010. - 297 с.

15. Ян Цзя. Языковая трансформация знаков европейской моды в китайской культуре / Ян Цзя // Личность. Культура. Общество. - 2011. - № 61. C. 217-221.

\section{REFERENCES}

1. Apresyan R.G., Gusseynov A.A. Demokratiya i grazhdanstvo [Democracy and Citizenship]. Voprosy filosofii, 1996, no. 7, pp. 3-16.

2. Benua A.N. Dnevnik 1916-1918 godov [Diary of 1916-1918]. Moscow, Zakharov Publ., 2010. 168 p.

3. Bogdanov A.A. Voprosy sotsializma: Raboty raznykh let [Issues of Socialism. Works of Different Years]. Moscow, Politizdat, 1990. 479 p.

4. Vodovozova E.N. Na zare zhizni. Memuarnye ocherki i portrety. V2 t. T. 2 [At Dawn of Life. Memoir Essays and Portraits. In 2 vols. Vol. 2]. Moscow, Khudozhestvennaya lit-ra Publ., 1987, vol. 2. 430 p.

5. Kirsanova R. «Gimnasterka», «Dzhimmi» i «polpred»... ['Gimnasterka', 'Dzhimmi' and 'Polpred'...]. Rodina, 1997, no. 11, pp. 46-50.

6. Klimova S.M., Gubareva O.V. Mif i simulyakr [Mith and Simulacr]. Chelovek, 2006, no. 6, pp. 34-37.

7. Redkina O.Yu. K rodnym beregam: o reemigratsii kazakov - «nekrasovtsev» iz Turtsii v SSSR v 1920-e gg. [To the Native Shore: about Remigration of Nekrasov Cossacks from Turkey to the USSR in the 1920s]. Istoricheskiy arkhiv, 2003, no. 5, pp. 109-126.

8. Kupriyanov A. Duratskie kostyumy [The Absurd Costumes]. Rodina, 2009, no. 1, pp. 104-107.

9. Petrova I.A., Avkhodeeva E.A. Kulturnye revolyutsii XX veka: razryv s traditsionnoy kulturoy ili ee prodolzhenie? [Cultural Revolutions of the $20^{\text {th }}$ Century: Break with the Traditional Culture or Its Continuation?]. Vestnik Volgogradskogo gosudarstvennogo universiteta. Seriya 7. Filosofiya. Sotsiologiya i sotsialnye tekhnologii [Science Journal of Volgograd State University. Philosophy. Sociology and Social Technologies], 2014, vol. 21, no. 1, pp. 13-20. 
10. Redkina O.Yu. Khristianskie politicheskie partii na Nizhney Volge v 1917 godu [Christian Political Parties in the Lower Volga in 1917]. Vestnik Volgogradskogo gosudarstvennogo universiteta. Seriya 4. Istoriya. Regionovedenie. Mezhdunarodnye otnosheniya [Science Journal of Volgograd State University. History. Area Studies. International Relations], 2012, no. 1,(16), pp. 121-126. DOI: http:// dx.doi.org/10.15688/jvolsu4.2012.1.6.

11. Smirnova T. Sovetskaya povsednevnost, narodnoe tvorchestvo i massovaya kultura 20-30 gg. [The Soviet Everyday Life, Folklore and Mass Culture During the 1920-1930s]. Istorik $i$ khudozhnik, 2003, no. 2, pp. 56-74.

12. Fuko M. Slova $i$ veshchi [The Order of Things]. Saint Petersburg, Akademiya Publ., 1994. 408 p.
13. Cheremushnikova I.K. Imidzh v epokhu «vosstaniya mass» [Image in the Age of "Mass Rebellion"]. Izvestiya Volgogradskogo gosudarstvennogo tekhnicheskogo universiteta. Seriya: Problemy sotsialno-gumanitarnogo znaniya. Volgograd, Izd-vo VolGTU, 2010, no. 9 (69), pp. 103-107.

14. Cheremushnikova I.K. Imidzh kak smyslovaya realnost kultury [Image as a Semantic Reality of Culture]. Volgograd, Izd-vo VolgMU, 2010. $297 \mathrm{p}$.

15. Yan Tszya. Yazykovaya transformatsiya znakov evropeyskoy mody v kitayskoy kulture [Language Transformation of European Fashion Signs in Chinese Culture]. Lichnost. Kultura. Obshchestvo, 2011, no. 61, pp. 217-221.

\section{Information about the Authors}

Maksim M. Zagorulko, Doctor of Sciences (Economics), Professor, Research Supervisor, Center for Study of the Battle of Stalingrad, Marshala Chuykova St., 45, 400005 Volgograd, Russian Federation, m.m.zagorulko@mail.ru, https://orcid.org/0000-0003-4701-9908

Irina A. Petrova, Doctor of Sciences (Philosophy), Professor, Head of Department of History and Cultural Studies, Volgograd State Medical University, Pavshikh Bortsov Sq., 1, 400131 Volgograd, Russian Federation, iapetrova51@gmail.com, https://orcid.org/0000-0002-6524-6939

Irina K. Cheremushnikova, Doctor of Sciences (Philosophy), Professor, Department of History and Cultural Studies, Volgograd State Medical University, Pavshikh Bortsov Sq., 1, 400131 Volgograd, Russian Federation, inhabitus@mail.ru, https://orcid.org/0000-0002-7211-0503

\section{Информация об авторах}

Максим Матвеевич Загорулько, доктор экономических наук, профессор, научный руководитель, Центр по изучению Сталинградской битвы, ул. им. Маршала Чуйкова, 45, 400005 г. Волгоград, Российская Федерация, m.m.zagorulko@mail.ru, https://orcid.org/0000-0003-4701-9908

Ирина Александровна Петрова, доктор философских наук, профессор, заведующая кафедрой истории и культурологии, Волгоградский государственный медицинский университет, площадь Павших Борцов, 1, 400131 г. Волгоград, Российская Федерация, iapetrova51@gmail.com, https:// orcid.org/0000-0002-6524-6939

Ирина Кабдрахимовна Черемушникова, доктор философских наук, профессор кафедры истории и культурологии, Волгоградский государственный медицинский университет, площадь Павших Борцов, 1, 400131 г. Волгоград, Российская Федерация, inhabitus@mail.ru, https://orcid.org/00000002-7211-0503 